\title{
Evaluation of newer fungicides against Alternaria alternata (Fr.) Keissler causing fruit rot disease of chilli
}

C.M. GINOYA AND N.M. GOHEL*

Department of Plant Pathology, B.A. College of Agriculture, Anand Agricultural University, ANAND (GUJARAT) INDIA

\section{ARITCLE INFO}

Received : 12.12 .2014

Revised : 06.03 .2015

Accepted : 20.03.2015

\section{KEY WORDS :}

Fungicides, Alternaria alternata, Fruit rot, Chilli, Capsicum annum, In vitro, In vivo

*Corresponding author:

Email: nareshgohel@aau.in

\begin{abstract}
Among the ten newer fungicides evaluated under in vitro condition by poisoned food technique against Alternaria alternata revealed tebuconazole, hexaconazole and azoxystrobin $(18.2 \%)+$ difenconazole (11.4\%) at all the three concentrations (500, 1000 and $1500 \mathrm{ppm})$ completely inhibited the mycelial growth of the pathogen and proved to be most effective. Based on in vitro screening, five promising fungicides were selected and reevaluated under field condition against fruit rot of chilli and the result revealed that two foliar application of tebuconazole $(50 \%)+$ trifloxystrobin (25\%) (75 WP) @ 0.05 per cent at an interval of 15 days, commencing from the initiation of disease was most effective in reducing fruit rot intensity and increasing fruit yield over control. Tebuconazole which was found effective under in vitro but could not reduce fruit rot intensity effectively under field conditions.
\end{abstract}

How to view point the article : Ginoya, C.M. and Gohel, N.M. (2015). Evaluation of newer fungicides against Alternaria alternata (Fr.) Keissler causing fruit rot disease of chilli. Internat. $J$. Plant Protec., 8(1) : 169-173. 